\title{
Mycobacterium Avium Complex Genitourinary Infections: Case Report and Literature Review
}

\author{
Sanu Rajendraprasad ${ }^{1}$, Christopher Destache ${ }^{2}$ and David Quimby ${ }^{1, *(D)}$ \\ 1 School of Medicine, Creighton University, Omaha, NE 68124, USA; SanuRajendraprasad@creighton.edu \\ 2 College of Pharmacy, Creighton University, Omaha, NE 68124, USA; chris.destache@creighton.edu \\ * Correspondence: david.quimbymd@commonspirit.org
}

check for updates

Citation: Rajendraprasad, S.;

Destache, C.; Quimby, D.

Mycobacterium Avium Complex Genitourinary Infections: Case

Report and Literature Review. Infect.

Dis. Rep. 2021, 13, 454-464.

https://doi.org/10.3390/idr13020045

Academic Editor: Nicola Petrosillo

Received: 6 May 2021

Accepted: 20 May 2021

Published: 24 May 2021

Publisher's Note: MDPI stays neutral with regard to jurisdictional claims in published maps and institutional affiliations.

Copyright: (c) 2021 by the authors. Licensee MDPI, Basel, Switzerland. This article is an open access article distributed under the terms and conditions of the Creative Commons Attribution (CC BY) license (https:// creativecommons.org/licenses/by/ $4.0 /)$.

\begin{abstract}
Nontuberculous mycobacterial (NTM) genitourinary (GU) infections are relatively rare, and there is frequently a delay in diagnosis. Mycobacterium avium-intracellulare complex (MAC) cases seem to be less frequent than other NTM as a cause of these infections. In addition, there are no set treatment guidelines for these organisms in the GU tract. Given the limitations of data this review summarizes a case presentation of this infection and the literature available on the topic. Many different antimicrobial regimens and durations have been used in the published literature. While the infrequency of these infections suggests that there will not be randomized controlled trials to determine optimal therapy, our case suggests that a brief course of amikacin may play a useful role in those who cannot tolerate other antibiotics.
\end{abstract}

Keywords: nontuberculous mycobacteria; mycobacterium avium-intracellulare complex; urinary tract infections; genitourinary infections

\section{Introduction}

In recent decades, the incidence and prevalence of nontuberculous mycobacteria (NTM) causing extrapulmonary infections have greatly increased, becoming a major worldwide public health problem [1,2]. Among numerous NTM species, the Mycobacterium avium complex (MAC) is the most common cause of infection in humans. MAC is recognized as a ubiquitous microorganism, with contaminated water and soil as established sources of infection [3]. MAC consists of multiple species, of which two of the most common are M.avium and M.intracellulare [4-6]. There are four main manifestations of MAC infection: (1.) HIV with disseminated disease; (2.) focal lymphadenitis also in predominantly HIV patients; (3.) pulmonary infection in those with structural lung disease; and (4.) skin and soft tissue infections [7-10]. Genitourinary tract infections secondary to MAC appear to be rare with questionable clinical relevance and no standardized treatment. Here we present a case of MAC-associated urinary tract infection in a woman with an extensive urological history and recurrent urinary tract infections.

\section{Case Presentation}

Patient is a 79-year-old woman with a complicated urologic history. Three years prior to her presentation in the infectious disease clinic, she had issues with urinary retention and frequent urinary tract infections, for which she would receive antibiotics. She required an indwelling urinary catheter for several months due to urinary retention, but voiding trials after initiation of tamsulosin were effective, and she was catheter-free for over 2 years prior to infectious disease clinic presentation. Recurrent infections were treated with methenamine and she had no symptoms of infection between November 2016 and June 2017. Starting in June 2017, she had more issues with urinary tract infection (UTI) symptoms, which improved with thrice-weekly vaginal estrogen cream and intermittent antibiotics.

Beginning in January 2019, however, her symptoms became near-constant. Repeated urine cultures were positive for methicillin-sensitive Staphylococcus aureus (Table 1); she was 
found to have some kidney stones, which were removed in February of 2019. Unfortunately, despite this intervention, she remained with constant symptoms, significantly affecting her quality of life. She underwent cystoscopy in August 2019 showing inflammation but no mass lesions; biopsies were not performed. Urine cytology showed no malignancy, abundant inflammation, and significant Candida. CT imaging of the abdomen and pelvis was significant only for a thickened bladder wall, consistent with cystitis. Given the persistent symptoms, pyuria, and relatively negative urine cultures (Table 1), she was treated with antifungal medication for the possibility of a true candida cystitis and had a urine sample sent for AFB culture. Given no improvement, she was started on silver nitrate bladder instillations by urology for symptomatic relief. The first treatment of silver nitrate bladder instillation led to an improvement in discomfort which was regrettably short-lived.

Table 1. Urine culture results 2016 to present.

\begin{tabular}{|c|c|c|c|}
\hline Date & Leucocyte Esterase & WBC/HPF & Culture \\
\hline $1 / 9 / 16$ & Large & $>100$ & $>100 \mathrm{~K}$ Pseudomonas aeruginosa, 20K MSSA \\
\hline $2 / 15 / 16$ & Small & $10-20$ & 50K MSSA \\
\hline $5 / 6 / 16$ & Large & $>100$ & $>100 \mathrm{~K}$ MSSA \\
\hline $5 / 10 / 16$ & Large & & 60K MSSA \\
\hline $5 / 21 / 16$ & Large & $>100$ & 50K Candida albicans \\
\hline $6 / 18 / 16$ & Large & $>100$ & $\begin{array}{c}\text { >100K Citrobacter freundii, } \\
>\text { 100K Enterococcus faecalis, } \\
\text { 10K mixed gram-positive flora }\end{array}$ \\
\hline $6 / 19 / 16$ & Large & 50-100 & $>100 \mathrm{~K}$ Candida albicans \\
\hline $6 / 28 / 16$ & & & 40K Candida albicans \\
\hline $8 / 31 / 16$ & Small & $10-20$ & $>100 \mathrm{~K}$ Proteus mirabilis \\
\hline $9 / 4 / 16$ & Large & Packed field & $>100 \mathrm{~K}$ Candida albicans \\
\hline $6 / 19 / 17$ & & & $>100 \mathrm{~K}$ MSSA \\
\hline $9 / 1 / 17$ & Large & & $>100 \mathrm{~K}$ MSSA \\
\hline $9 / 15 / 17$ & Large & & 50K MSSA \\
\hline $9 / 20 / 17$ & Large & $>100$ & 40K MSSA \\
\hline $2 / 6 / 18$ & Large & & 5K mixed Gram-positive flora \\
\hline $7 / 16 / 18$ & Large & & 40K MSSA \\
\hline $8 / 21 / 18$ & Large & & 30K MSSA, 6K mixed Gram-positive flora \\
\hline $11 / 16 / 18$ & Moderate & & $>100 \mathrm{~K}$ MSSA \\
\hline $1 / 7 / 19$ & Moderate & & 20K MSSA \\
\hline $1 / 19 / 19$ & Small & $20-50$ & $400 \mathrm{CFU}$ yeast \\
\hline $3 / 9 / 19$ & Moderate & $>100$ & $2 \mathrm{~K}$ yeast \\
\hline $8 / 19 / 19$ & Moderate & Packed field & $4 \mathrm{~K}$ yeast \\
\hline $9 / 5 / 19$ & & & Mycobacterium avium complex \\
\hline $10 / 15 / 19$ & Large & & AFB culture negative \\
\hline $11 / 5 / 19$ & Moderate & & 30K Enterococcus faecalis, $20 \mathrm{~K}$ yeast \\
\hline $12 / 8 / 19$ & Moderate & $>100$ & $20 \mathrm{~K}$ normal urogenital flora \\
\hline $12 / 23 / 19$ & Large & & 20K yeast, $10 \mathrm{~K}$ Enterococcus faecalis \\
\hline $1 / 3 / 20$ & Large & Packed field & $50 \mathrm{~K}$ yeast \\
\hline $9 / 20 / 20$ & Negative & $<5$ & No growth \\
\hline $2 / 25 / 2021$ & Negative & $<5$ & No growth \\
\hline
\end{tabular}

WBC/HPF—white blood cells/high power field, MSSA—-methicillin-susceptible Staphylococcus aureus, AFB-acid-fast bacillus, CFU—colony forming unit. 
Prior to the second planned instillation of silver nitrate, her urine AFB culture was positive for Mycobacterium avium complex via the nucleic acid DNA probe (AccuProbe Mycobacterium avium complex culture identification test, Hologic). In October 2019, she was started on an antimicrobial regimen of clarithromycin $500 \mathrm{mg}$ BID, rifampin (RIF) $600 \mathrm{mg} /$ day, and ethambutol $1200 \mathrm{mg} /$ day based on susceptibilities (Table 2) and continued with the silver nitrate instillations for about a month given a little improvement after starting them. The instillations were discontinued due to intolerable bladder spasms. Unfortunately, despite antimicrobial therapy, she remained quite symptomatic and was having increasing nausea from the medications.

Table 2. Mycobacterium avium complex susceptibility.

\begin{tabular}{ccc}
\hline Antimicrobial & MIC & Interpretation \\
\hline Amikacin IV & 2 & Sensitive \\
Amikacin-Liposomal, Inhaled & 2 & Sensitive \\
Clarithromycin & 0.25 & Sensitive \\
Linezolid & $\leq 1$ & Sensitive \\
Moxifloxacin & 0.25 & Sensitive \\
\hline
\end{tabular}

Abbreviation: MIC, minimum inhibitory concentration.

In January 2020, due to gastrointestinal symptoms from medications, lack of improvement in pyuria, and lack of improvement in her dysuria, the antimicrobial regimen was changed to rifampin $600 \mathrm{mg} /$ day, linezolid $600 \mathrm{mg} /$ day, and three-times-weekly amikacin. After the first week of this regimen, she had significant improvement in her urinary symptoms. By the end of the second week, she was completely asymptomatic. She completed three weeks of the amikacin and was then maintained on linezolid and rifampin alone. Follow-up urinalysis showed marked improvement in pyuria, and she remained asymptomatic. For the next ten months, she remained symptom-free from a urinary standpoint and tolerated the linezolid/rifampin combination with no ill effects. She completed twelve months of therapy from initiation of the amikacin with a follow-up urine analysis demonstrating no pyuria. A second urine analysis a few weeks the first was also negative. Interestingly, a second urinary AFB culture obtained prior to any antimycobacterial therapy (but after the first silver nitrate instillation) was ultimately negative.

\section{Nontuberculous Mycobacteria: An Overview}

Among numerous NTM species, MAC is the most predominant group causing disease in humans. Originally not recognized as pathogenic, in the 1950s, the isolation of acid-fast bacilli with atypical cultural characteristics was noted at Battey State hospital, Rome, Georgia USA. At this time there developed evidence of direct causation of disease [11,12]. In 1959, Runyon proposed the first classification of NTM into four groups, the first three comprising "Slowly Growing Mycobacteria" (SGM) and the fourth of "Rapidly Growing Mycobacteria" [5]. MAC is part of group III or Battey type NTM in the Runyon classification [13]. With advances in the systematic analysis we are able to identify and classify new (sub) species within MAC at the molecular level. The most common SGM is the species belonging to the Mycobacterium avium complex (MAC), comprising especially Mycobacterium avium and Mycobacterium intracellulare.

The incidence of MAC infections is increasing in most industrialized countries, possibly because of the increase in immunocompromised and/or older patients [1,2]. In addition, improvement in testing methods to culture and identify have spurred increases in MAC have likely led to increased diagnoses. The use of fluorescent stain and fluorescent microscope appears to be superior to Ziehl-Neelson stain for AFB smear [14]. AFB culture in liquid Mycobacteria Growth Indicator Tube (MGIT) has replaced the LowensteinJensen slant in isolating NTM and DNA probes and matrix-assisted laser desorption ionization-time of flight mass spectrometry (MALDI-TOF) allows for precise identification in hours compared to the traditional biochemical and phenotypic methods that can take weeks $[15,16]$. 


\section{Mycobacterial Genitourinary (GU) Infections: Clinical Presentation}

Mycobacterial genitourinary (GU) tract infections are a not-uncommon event, and genitourinary tract tuberculosis is a common manifestation of extrapulmonary TB. In genitourinary tuberculosis, men are more frequently infected than women, and HIVinfected men are at the highest risk [17]. Initial presentation is not always associated with specific symptoms; pyuria and/or microscopic hematuria may be observed as incidental findings. Involvement of the bladder may cause symptoms of frequency, dysuria, urgency, and nocturia in approximately half of the cases; gross hematuria and low back pain develop in $1 / 3$ of cases. Systemic symptoms (fever, weight loss) are relatively rare [18]. While there are good data on prevalence and therapeutic options for tubercular GU infections, non-tubercular (NTM) infections of the GU tract are much less common, and there is currently no standard approach to therapy.

Most cases that have been documented of genitourinary NTM showed increased prevalence in women. Infections are more common in the elderly population, although a case of genitourinary MAC associated with disseminated infection has been reported in a child as young as 14 years [19]. Genitourinary infection does not appear to be isolated to the immunocompromised, as only one infection in a transplant recipient has been documented [20]. Most patients appear immunocompetent. It is unclear if race is a factor; of the published cases, most patients are Caucasian, but lack of diagnosis and publication bias could play a role in this.

Primary complaints of UTI appear to be present in all those that have been diagnosed with MAC as the etiology of their symptoms. Duration of symptoms varies from 1 week to 3 years. Several patients appear to have been treated with antibiotics for suspected bacterial urinary tract infections in the past. Sterile pyuria in routine urine culture with dysuria appears to be a common presenting sign. Of interest is the duration of symptoms and persistence of symptoms after routine treatment with antibiotics. In our patient, she has grown multiple bacterial organisms in the urine cultures over the years including Candida species with some improvement in symptoms until the next recurrence. Other NTM (M. abscessus, $M$. fortuitum, $M$. gordonae) causing genitourinary infection do not have a similar presentation [21-27].

The most common species of rapidly growing mycobacteria of clinical relevance are M.fortuitum, M.abscessus, M.marinum, and M.chelonae. While predominantly known to cause skin and soft tissue infections, these pathogens can cause disease in other parts of the body, including the GU tract, and there are increasing published reports of these organisms leading to infection in this organ system. M. fortuitum has been associated with prolonged urinary tract elimination in patients with AIDS as well as hemodialysis patients $[23,25]$. While it is not always clear that the presence of these pathogens in a urine culture is necessarily reflective of true infection, in several cases there has been clinical evidence of true disease, and antimicrobial treatment led to culture sterilization and clinical improvement (Table 3) [20,28-32]. 
Table 3. MAC case reports.

\begin{tabular}{|c|c|c|c|c|c|c|c|c|c|}
\hline Year & Reference & Age/Sex & Race & Clinical Findings & $\begin{array}{l}\text { Duration of } \\
\text { Symptoms }\end{array}$ & $\begin{array}{c}\text { Organism in } \\
\text { Urine }\end{array}$ & Susceptibility & Treatment & Outcome \\
\hline 1963 & Faber et al. [29] & $27 / F$ & $\begin{array}{c}\text { Japanese- } \\
\text { American }\end{array}$ & $\begin{array}{l}\text { Gross hematuria. } \\
\text { Left renal mass }\end{array}$ & 1 week & $\begin{array}{l}\text { Atypical AFB } \\
\text { (Battey type) }\end{array}$ & $\mathrm{N} / \mathrm{A}$ & $\begin{array}{l}\text { Empirically started } \\
\text { Streptomycin } 1 \mathrm{~g} / \text { day, } \\
\text { INH } 250 \mathrm{mg} / \text { day. } \\
\text { One month in decrease } \\
\text { streptomycin to twice a week. } \\
\text { Total duration } 4 \text { months }\end{array}$ & $\begin{array}{c}\text { Removal of left renal mass } \\
\text { (pathology showed no AFB) } \\
\text { after surgery pt } \\
\text { was asymptomatic }\end{array}$ \\
\hline 1966 & Newman, H. [30] & $52 / \mathrm{F}$ & Caucasian & $\begin{array}{c}\text { Pyuria and } \\
\text { dysuria }\end{array}$ & $\begin{array}{c}10 \text { days, } \\
\text { Intermittent } \\
\text { dysuria since } \\
\text { teenager, similar } \\
\text { symptoms after } \\
2 \text { years }\end{array}$ & $\begin{array}{l}2 \text { cultures grew } \\
3 \text { atypical } \\
\text { mycobacteria } \\
\text { and one group } \\
4 \text { rapid growers }\end{array}$ & N/A & $\begin{array}{l}\text { Streptomycin } 1 \mathrm{~g} \text { twice a } \\
\text { week, INH } 300 \mathrm{mg} / \text { day }+ \\
\text { PAS } 12 \mathrm{~g} \text { daily for } 12 \text { months, } \\
\text { after which INH and PAS } \\
\text { were continued for another } \\
6 \text { months }\end{array}$ & $\begin{array}{l}\text { Symptomatic improvement. } \\
\text { Had left nephroureterectomy } \\
\text { which showed } \\
\text { granulomatosis changes } \\
\text { consistent with tuberculosis. } \\
\text { Urine sterilization } \\
\text { after procedure. }\end{array}$ \\
\hline 1973 & $\begin{array}{l}\text { Pergament et al. } \\
{[31]}\end{array}$ & $62 / \mathrm{F}$ & $\begin{array}{l}\text { Presumed } \\
\text { Caucasian }\end{array}$ & $\begin{array}{l}\text { Frequency, } \\
\text { urgency, nocturia, } \\
\text { suprapubic pain } \\
\text { and right lower } \\
\text { quadrant pain } \\
\text { with gross } \\
\text { hematuria }\end{array}$ & 6 months & $\begin{array}{l}\text { Battey-avian } \\
\text { complex }\end{array}$ & $\begin{array}{l}\text { Sensitive: INH, } \\
\text { RIF, EMB }\end{array}$ & $\begin{array}{l}\text { INH } 300 \mathrm{mg} / \text { day, RIF } \\
600 \mathrm{mg} / \text { day, EMB } \\
15 \mathrm{mg} / \mathrm{kg} / \text { day and } \\
\text { Streptomycin } 1 \mathrm{~g} 3 \text { times a } \\
\text { week for total of } 6 \text { weeks }\end{array}$ & $\begin{array}{l}\text { Patient continued to have } \\
\text { symptoms but achieved } \\
\text { urine sterilization }\end{array}$ \\
\hline 1986 & Mikolich et al. [32] & $75 / \mathrm{M}$ & $\begin{array}{l}\text { Presumed } \\
\text { Caucasian }\end{array}$ & $\begin{array}{l}\text { Granulomatous } \\
\text { Prostatitis, Difficulty } \\
\text { urinating with } \\
\text { hematuria and pyuria }\end{array}$ & 1 year & MAC & $\begin{array}{l}\text { Initial culture: Sensitive: } \\
\text { PZA; Resistant: INH, } \\
\text { EMB, streptomycin and } \\
\text { RIF. CDC sensitivities to } \\
\text { initial culture: Sensitive: } \\
\text { ansamycin Resistant: } \\
\text { Capreomycin, } \\
\text { streptomycin, INH, PAS, } \\
\text { RIF, EMB, kanamycin, } \\
\text { PZA, cycloserine } \\
\text { and ethionamide }\end{array}$ & $\begin{array}{c}\mathrm{INH} 300 \mathrm{mg} / \text { day, RIF } \\
600 \mathrm{mg} / \text { day } \times 4 \text { months, } \\
\text { EMB } 1 \mathrm{~g} / \text { day }+ \text { PZA } \\
1.5 \mathrm{~g} / \text { day. No change, } \\
6 \text { weeks of ansamycin } \\
300 \mathrm{mg} / \text { day, INH } \\
300 \mathrm{mg} / \text { day, EMB } 1 \mathrm{~g} / \text { day } \\
+1 \mathrm{~g} \text { of streptomycin IM } \\
3 \text { times a week for } 1 \text { week } \\
\text { then twice weekly for } \\
\text { total of } 6 \text { weeks }\end{array}$ & $\begin{array}{l}\text { No improvement with } \\
\text { treatment. Some } \\
\text { improvement with NSAIDs }\end{array}$ \\
\hline
\end{tabular}


Table 3. Cont.

\begin{tabular}{|c|c|c|c|c|c|c|c|c|c|}
\hline Year & Reference & Age/Sex & Race & Clinical Findings & $\begin{array}{l}\text { Duration of } \\
\text { Symptoms }\end{array}$ & $\begin{array}{l}\text { Organism in } \\
\text { Urine }\end{array}$ & Susceptibility & Treatment & Outcome \\
\hline 2015 & Obeid et al. [20] & $61 / F$ & Somali born & $\begin{array}{l}\text { Liver cirrhosis } \\
\text { with chronic } \\
\text { dysuria, } \mathrm{s} / \mathrm{p} \\
\text { transplant with } \\
\text { recurrence }\end{array}$ & $\begin{array}{l}\text { Unclear } \\
\text { duration }\end{array}$ & MAI & $\begin{array}{c}\text { Sensitive to } \\
\text { Clarithromycin, } \\
\text { Moxifloxacin, Linezolid }\end{array}$ & $\begin{array}{l}\text { Azithromycin } 250 \mathrm{mg} / \text { day, } \\
\text { EMB } 1200 \mathrm{mg} / \text { day, RIF } \\
600 \mathrm{mg} / \text { day (substituted } \\
\text { rifabutin), Moxifloxacin } \\
400 \mathrm{mg} / \text { day- } \\
17 \text { months total }\end{array}$ & $\begin{array}{l}\text { Urine sterilization in } \\
5 \text { months and completed } \\
17 \text { months of treatment. } \\
\text { With } 1 \text { year of therapy after } \\
\text { first negative mycobacterial } \\
\text { urine culture. Recurrence } \\
\text { after } 8 \text { months of orthotopic } \\
\text { liver and kidney transplant. } \\
\text { Refused treatment and pt } \\
\text { died unrelated to MAI }\end{array}$ \\
\hline 2018 & $\begin{array}{c}\text { Miyashita et al. } \\
\text { [28] }\end{array}$ & $63 / F$ & $\begin{array}{l}\text { Presumed } \\
\text { Japanese }\end{array}$ & $\begin{array}{l}\text { Disseminated } \\
\text { MAC initially } \\
\text { presented with } \\
\text { fever, eruption } \\
\text { and sterile pyuria }\end{array}$ & $\begin{array}{l}\text { Unclear } \\
\text { duration }\end{array}$ & MAC & $\mathrm{N} / \mathrm{A}$ & $\begin{array}{c}\text { Clarithromycin } 800 \mathrm{mg} / \text { day, } \\
\text { RIF } 450 \mathrm{mg} / \text { day, EMB } \\
750 \mathrm{mg} / \text { day, (streptomycin } \\
600 \mathrm{mg} / \text { day } \times \\
3 \text { days }-2 \text { months) }\end{array}$ & $\begin{array}{l}1 \text { month after treatment } \\
\text { afebrile, resolution of urinary } \\
\text { incontinence-Regression of } \\
\text { multiple organ involvement } \\
\text { except splenic lesions-Over } \\
20 \text { months of therapy }\end{array}$ \\
\hline 2019 & Present case & $79 / \mathrm{F}$ & Caucasian & $\begin{array}{c}\text { Recurrent } \\
\text { symptomatic UTI }\end{array}$ & 3 years & MAC & $\begin{array}{l}\text { Sensitive: Amikacin, } \\
\text { Clarithromycin, } \\
\text { Linezolid and } \\
\text { Moxifloxacin }\end{array}$ & $\begin{array}{l}\text { Clarithromycin } 500 \mathrm{mg} \text { po } \\
\text { BID, RIF } 600 \mathrm{mg} \text { po daily } \\
\text { and EMB } 1200 \mathrm{mg} \text { po daily } \\
\text { changed treatment after } \\
4 \text { months to continue RIF } \\
600 \mathrm{mg} / \text { day, linezolid } \\
\quad 600 \mathrm{mg} / \text { day, and } \\
\text { three-times-weekly amikacin } \\
\text { for } 3 \text { weeks. }\end{array}$ & $\begin{array}{l}\text { Asymptomatic after } \\
12 \text { months of treatment. } \\
\text { Urine sterilization. }\end{array}$ \\
\hline
\end{tabular}

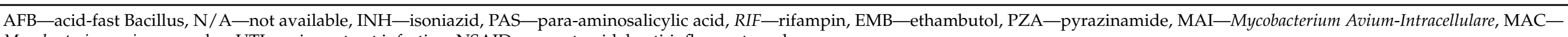
Mycobacterium avium complex, UTI—urinary tract infection, NSAIDs—nonsteroidal anti-inflammatory drugs. 
Urinary involvement with disseminated spread has been associated with underlining cell-mediated immune deficiencies or serum interferon-Y-neutralizing autoantibodies $[19,28]$. None of the patients appear to have any history of HIV which has been associated with disseminated MAC. One of the patients that completed treatment and had sterilization of urine was found to have a recurrence after undergoing orthotopic liver and kidney transplant and being placed on immunosuppression. It is unclear if immunosuppression definitively increases the risk of isolated GU infection secondary to MAC as noted in Obeid et al. [20].

Studies question the clinical significance of MAC in the urine as some patients are not treated with antibiotics and managed conservatively [33-35]. Like other potential pathogens isolated on cultures, the presence of a positive culture does not necessarily mean true infection: in one large New York hospital over a 3-year period, there were $422 \mathrm{HIV}$ negative patients with cultures positive for MAC from various body sites. Of these, 375 had clinical data available to determine true mycobacterial infection or not, of which only 119 felt to have a true infection. One patient had repeated positive urine cultures for MAC but was not categorized as having NTM disease since the patient was asymptomatic [36]. Additionally, it has been suggested that about 43\% (12/28 tested) of HIV+ individuals with disseminated MAC infection will have positive urine cultures for this organism [37]. Two reported patients continued to be symptomatic, despite achieving urine sterilization, which raises the question if treatment was beneficial or necessary [31,32]. Two patients had renal involvement requiring surgical management in addition to antibiotic therapy which led to symptomatic improvement and urine sterilization $[29,30]$. Thus, proper source control may have provided a similar effect. Given the lack of susceptibility information or standardization of care with antibiotics and duration of treatment, it is difficult to form a firm conclusion.

\section{Mycobacterial GU Infections: Diagnosis}

General practice for patients with ongoing culture-negative urinary symptoms often involves cultures for atypical organisms (such as Chlamydia, Gonorrhoea, Mycoplasma, Ureaplasma, and mycobacterial organisms). Molecular techniques have been explored, and one study used nucleic acid probes of tissue from bladder wall biopsy of patients with interstitial cystitis to look for missed mycobacterial pathogens; of the eight tested, none were positive suggesting that this may not be a common cause of ongoing culture-negative urinary symptoms in this small study [38]. However, there are clear cases where MAC has been implicated in true GU tract infections (Table 3) with consistent symptoms, positive cultures, and clinical benefit from antimicrobial therapy. However, the optimal treatment of medications and duration is not clear at this time.

Our patient exemplifies the difficulty in making a diagnosis of NTM GU tract infection. She had ongoing symptoms for years, constant pyuria on cultures, and was treated repeatedly for small-quantity colonizing bacteria with no clinical improvement. In addition, like many patients with recurrent GU issues, she had more than one problem along the way: initially she had urinary retention, and later developed colonized/infected kidney stones. AFB culture was sent after evaluation by infectious diseases clinic and returned positive after four weeks of incubation. Prior to starting therapy, the culture was repeated, but ultimately reported as negative perhaps as a result of the intermittent intravesicular silver nitrate installations for symptomatic relief. Studies have shown silver nanoparticles (AgNPs) demonstrate antimycobacterial effect in bacterial cultures and within macrophages [39]. The use of monthly silver nitrate installations in conjunction with antibiotic management may have been the key to the eradication of the infection in this patient.

\section{Mycobacterial GU Infections: Treatment}

Treatment for genitourinary mycobacterial infection has not been standardized. Initial regimens appeared to favor isoniazid (INH), ethambutol (EMB), RIF, and strepto- 
mycin [29-32]. All except Faber et al. used three drug regimens to initiate treatment with modifications as needed for each patient, despite which urine sterilization was achieved. Recent case reports show a shift to macrolide (azithromycin or clarithromycin) based treatment with the use of Clinical and Laboratory Standards Institute (CLSI) published guidelines for drug susceptibility testing (DST) of NTM in 2011 and updated in 2018. Along with macrolides, RIF, EMB, fluoroquinolones, and aminoglycosides have been used as additional medications for three drug antibiotic therapy [20,28].

Treatment for genitourinary MAC does appear to be extrapolating from pulmonary MAC treatment which is based on macrolides combined with a rifamycin (rifampin or rifabutin) and ethambutol. The use of amikacin can be parenteral or inhaled in for severe cases of pulmonary MAC $[7,40]$, although older case reports show streptomycin $(600 \mathrm{mg}-$ $1 \mathrm{~g})$ as the most common addition in 5 out of 7 cases [28-32]. Moxifloxacin, bedaquiline, linezolid, and clofazimine are alternative drugs proposed mainly for the treatment of infections caused by macrolide-resistant pulmonary MAC [41].

In NTM lung disease, CLSI and the British Thoracic Society (BTS) recommend testing the isolate for clarithromycin and amikacin susceptibility prior to the initiation of therapy. It is reasonable to assume that genitourinary infections would benefit from similar testing. In cases of resistance to clarithromycin, CLSI recommends DST of moxifloxacin and linezolid, whereas BTS recommends testing a wider panel of antibiotics to guide treatment regimens [42-44]. Ethambutol and rifamycins, unfortunately, have no clinical breakpoints defined for treatment of MAC infections [41].

The use of these antimicrobials does require further evaluation regarding pharmacokinetics with special consideration of urine concentration achieved by each. Linezolid, clarithromycin, clofazimine, and aminoglycosides (streptomycin and amikacin) achieve the highest levels in urine as noted in Table 4. It is not certain how relevant urine antimicrobial concentrations are, as the use of oral medications with lower urinary concentration often leads to urinary sterilization.

Table 4. Pharmacokinetics of antimycobacterial drugs with urine concentration.

\begin{tabular}{ccc}
\hline Drug & Dose & Urinary Drug Level $(\mu \mathrm{g} / \mathrm{mL})$ \\
\hline Clarithromycin [45] & $500 \mathrm{mg} \mathrm{BID}$ & $\sim 1.24$ \\
Azithromycin [46] & $500 \mathrm{mg} \mathrm{qd}$ & $\sim 148$ \\
Rifampin [47] & $600 \mathrm{mg} \mathrm{qd}$ & $400-600$ \\
Ethambutol [48] & $25 \mathrm{mg} / \mathrm{kg} / \mathrm{d}$ & $7-9$ \\
Streptomycin [49] & $600 \mathrm{mg} \mathrm{IM} \mathrm{qd}$ & $174-534$ \\
Amikacin [50] & $500 \mathrm{mg} \mathrm{IM} \mathrm{qd}$ & $600-832$ \\
Linezolid [51] & $600 \mathrm{mg} \mathrm{BID} \mathrm{po}$ & $192-61$ \\
Moxifloxacin [52] & $400 \mathrm{mg}$ qd po & $\sim 137.6$ \\
Bedaquiline [53] & $400 \mathrm{mg}$ po qd & $\sim 4$ \\
Clofazimine [54] & $100 \mathrm{mg} \mathrm{3} \mathrm{times/wk}$ & $156-456$ \\
\hline
\end{tabular}

Based on the minimal amount of published data on Mycobacterium avium complex genitourinary infections, optimal therapy and duration are unclear at this time. Patients have been treated with several regimens with varying duration of treatment ranging from 6 weeks to 18 months. While likely rare enough to make randomized trials of different therapeutic options impossible, this case suggests that relatively brief therapy with amikacin may be of benefit. The practice of confirming pathogen clearance with repeat sputum culture in pulmonary MAC could be transitioned to genitourinary MAC infection with the determination of duration of treatment after urine sterilization. While the ideal duration of both aminoglycoside therapy and total therapy is unclear, patient symptoms and degree of pyuria may be of benefit in measuring disease activity even in the face of negative follow-up cultures. 


\section{Conclusions}

Genitourinary Mycobacterium avium complex infection appears to be rare. Patients commonly have symptoms with dysuria and sterile pyuria for prolonged periods prior to proper diagnosis. Concern of clinical relevance despite urine culture positivity is present although our case in addition to prior reports of similar patients confirms the need for aggressive and prolonged management to provide symptomatic relief when true infection, and not just colonization, is present. Based on data from the more-common pulmonary infections, beginning with three-drug therapy and evaluation of sensitivity to macrolides and aminoglycosides is recommended. A short course of aminoglycoside for genitourinary MAC may be beneficial in some patients. Overall duration of therapy is unclear, as literature review shows a wide range of therapy, ranging from six weeks to 18 months. Optimal medication choice and antibiotic duration may require tailoring to each individual patient.

Author Contributions: Writing manuscript, original draft: S.R., D.Q. Writing manuscript, revisions: S.R., C.D., D.Q. Literature search: S.R., D.Q. Table preparation: S.R., C.D. Manuscript submission: D.Q. All authors have read and agreed to the published version of the manuscript.

Funding: This research received no external funding.

Institutional Review Board Statement: Not applicable.

Informed Consent Statement: Written consent has been obtained from the patient to publish this paper.

Data Availability Statement: Not applicable.

Conflicts of Interest: The authors declare no conflict of interest.

\section{Abbreviations}

$\begin{array}{ll}\text { AFB } & \text { Acid-fast bacillus } \\ \text { AgNPs } & \text { silver nanoparticles } \\ \text { AIDS } & \text { Acquired immunodeficiency syndrome } \\ \text { BTS } & \text { British Thoracic Society } \\ \text { CLSI } & \text { Clinical and Laboratory Standards Institute } \\ \text { DST } & \text { Drug susceptibility testing } \\ \text { EMB } & \text { ethambutol } \\ \text { GU } & \text { Genitourinary } \\ \text { HIV } & \text { Human immunodeficiency virus } \\ \text { INH } & \text { isoniazid } \\ \text { MAC } & \text { Mycobacterium avium complex } \\ \text { MAI } & \text { Mycobacterium Avium-Intracellulare } \\ \text { MALDI-TOF } & \text { matrix-assisted laser desorption ionization-time of flight mass spectrometry } \\ \text { MGIT } & \text { Mycobacteria growth indicator tube } \\ \text { NTM } & \text { Nontuberculous mycobacteria } \\ \text { RIF } & \text { Rifampin } \\ \text { SGM } & \text { Slowly growing mycobacteria } \\ \text { UTI } & \text { Urinary tract infection }\end{array}$

\section{References}

1. Arend, S.M.; van Soolingen, D.; Ottenhoff, T.H. Diagnosis and treatment of lung infection with nontuberculous mycobacteria. Curr. Opin. Pulm. Med. 2009, 15, 201-208. [CrossRef] [PubMed]

2. Jones, M.M.; Winthrop, K.L.; Nelson, S.D. Epidemiology of nontuberculous mycobacterial infections in the U.S. Veterans Health Administration. PLOS ONE 2018, 13, e0197976. [CrossRef] [PubMed]

3. Falkinham, J.O., 3rd. Surrounded by mycobacteria: Nontuberculous mycobacteria in the human environment. J. Appl. Microbiol. 2009, 107, 356-367. [CrossRef] [PubMed]

4. Turenne, C.Y.; Wallace, R., Jr.; Behr, M.A. Mycobacterium avium in the postgenomic era. Clin. Microbiol. Rev. 2007, 20, 205-229. [CrossRef]

5. Runyon, E.H. Pathogenic mycobacteria. Bibl. Tuberc. 1965, 21, 235-287. 
6. $\quad$ van Ingen, J.; Turenne, C.Y.; Tortoli, E.; Wallace, R.J., Jr.; Brown-Elliott, B.A. A definition of the Mycobacterium avium complex for taxonomical and clinical purposes, a review. Int. J. Syst. Evol. Microbiol. 2018, 68, 3666-3677. [CrossRef]

7. Griffith, D.E.; Aksamit, T.; Brown-Elliott, B.A.; Catanzaro, A.; Daley, C.; Gordin, F.; Holland, S.M.; Horsburgh, R.; Huitt, G.; Iademarco, M.F.; et al. An official ATS/IDSA statement: Diagnosis, treatment, and prevention of nontuberculous mycobacterial diseases. Am. J. Respir. Crit. Care Med. 2007, 15, 367-416. [CrossRef]

8. Tortoli, E. Clinical manifestations of nontuberculous mycobacteria infections. Clin. Microbiol. Infect. 2009, 15, 906-910. [CrossRef] [PubMed]

9. Johnson, M.M.; Odell, J.A. Nontuberculous mycobacterial pulmonary infections. J. Thorac. Dis. 2014, 6, 210-220. [CrossRef]

10. McShane, P.J.; Glassroth, J. Pulmonary Disease Due to Nontuberculous Mycobacteria: Current State and New Insights. Chest 2015, 148, 1517-1527. [CrossRef]

11. Corpe, R. Clinical aspects, medical and surgical, in the management of Battey-type pulmonary disease. Dis. Chest 1964, 45, 380-382. [CrossRef]

12. Feldman, W.; Ritts, R. Pathogenicity studies of group III (Battey) Mycobacteria from pulmonary lesions of man. Dis. Chest 1963, 43, 26-33. [CrossRef] [PubMed]

13. Crow, H.E.; King, C.T.; Smith, C.E.; Corpe, R.F.; Stergus, I. A limited clinical, pathologic, and epidemiologic study of patients with pulmonary lesions associated with atypical acid-fast bacilli in the sputum. Am. Rev. Tuberc. 1957, 75, 199-222. [CrossRef] [PubMed]

14. Annam, V.; Kulkarni, M.H.; Puranik, R.B. Comparison of the modified fluorescent method and conventional Ziehl-Neelsen method in the detection of acidfast bacilli in lymphnode aspirates. Cytojournal 2009, 6, 13. [CrossRef]

15. Pfyffer, G.E.; Welscher, H.M.; Kissling, P. Comparison of the Mycobacteria Growth Indicator Tube (MGIT) with radiometric and solid culture for recovery of acid-fast bacilli. J. Clin. Microbiol. 1997, 35, 364-368. [CrossRef]

16. Balada-Llasat, J.M.; Kamboj, K.; Pancholi, P. Identification of mycobacteria from solid and liquid media by matrix-assisted laser desorption ionization-time of flight mass spectrometry in the clinical laboratory. J. Clin. Microbiol. 2013, 51, 2875-2879. [CrossRef]

17. Zajaczkowski, T. Genitourinary tuberculosis: Historical and basic science review: Past and present. Cent. Eur. J. Urol. 2012, 65, 182-187. [CrossRef] [PubMed]

18. Kapoor, R.; Ansari, M.S.; Mandhani, A.; Gulia, A. Clinical presentation and diagnostic approach in cases of genitourinary tuberculosis. Indian J. Urol. 2008, 24, 401-405. [CrossRef]

19. Thomas, E.; Hillman, B.J.; Stanisic, T. Urinary tract infection with atypical mycobacteria. J. Urol. 1980, 124, 748-750. [CrossRef]

20. Obeid, K.M.; Hassan, M.A.; Chinnakotla, S.; Young, J.H. Genitourinary Tract Infection Due to Mycobacterium avium intracellulare Complex Infection in Pretransplant Setting With Recurrence Following Transplant: A Case Report. Transpl. Proc. 2018, 50, 3937-3939. [CrossRef]

21. Hochman, I.; Siegman-Igra, Y.; Goor, Y.; Cabili, S. A case of prolonged urinary tract infection caused by Mycobacterium fortuitum. Eur. J. Clin. Microbiol. Infect. Dis. 1992, 11, 725-727. [CrossRef]

22. Traore, B.; Fongoro, S.; Timbine, L.G.; Diallo, D.; Toure, A.; Djigulba, K.; Yattara, H.; Kouriba, B.; Diallo, S. Mycobacterium abscessus urinary infection in a hypertensive patient: A case report. Mycobact. Dis. 2016, 6, 224. [CrossRef]

23. Serra, C.; Loi, G.; Saddi, B.; Pautasso, M.; Manzin, A. Unusual clinical presentation of Mycobacterium fortuitum infection in an immunocompetent woman. J. Clin. Microbiol. 2007, 45, 1663-1665. [CrossRef] [PubMed]

24. Laudelino, J.S.; Farias Filho, F.T.; Costa, A.F.P.; Santos, V.M. Mycobacterium abscessus urinary tract infection: Case report. J. Bras. Nefrol. 2020, 42, 124-126. [CrossRef] [PubMed]

25. Ersoz, G.; Kaya, A.; Cayan, S. Urinary Mycobacterium fortuitum infection in an HIV-infected patient. AIDS 2000, 14, 2802-2803. [CrossRef]

26. Case Report: Urinary Mycobacterium Gordonae. Available online: https://print.ispub.com/api/0/ispub-article/13628 (accessed on 2 March 2021).

27. Mehanni, S.M.D.; Joseph, K.M.D.; Casanas, B.D.O.; Greene, J.M.D. Mycobacterium Abscessus Granulomatous Cystitis in a Patient With Superficial Bladder Cancer. Infect. Dis. Clin. Pract. 2014, 22, 116-117. [CrossRef]

28. Miyashita, K.; Matsuura, S.; Tajima, K.; Tajima, S.; Aoki, A.; Sakagami, T.; Koshimizu, N.; Toyoshima, M.; Suda, T. Disseminated Mycobacterium avium infection presenting with bladder lesions in a patient with interferon-gamma-neutralizing autoantibodies. Intern. Med. 2018, 57, 3041-3045. [CrossRef]

29. Faber, D.R.; Lasky, I.I.; Goodwin, W.E. Idiopathic unilateral renal hematuria associated with atypical Acid-fast Bacillus: Battey type. Cure by partial nephrectomy. J. Urol. 1965, 93, 435-439. [CrossRef]

30. Newman, H. Renal disease associated with atypical mycobacteria: Battey type. Case Rep. J. Urol. 1970, 103, 403-405. [CrossRef]

31. Pergament, M.; Gonzalez, R.; Fraley, E.E. Atypical Mycobacteriosis of the Urinary Tract: A Case Report of Extensive Disease Caused by the Battey Bacillus. JAMA 1974, 229, 816-817. [CrossRef]

32. Mikolich, D.J.; Mates, S.M. Granulomatous prostatitis due to Mycobacterium avium complex. Clin. Infect. Dis. 1992, 14, 589-591. [CrossRef]

33. Klotz, P.G. Atypical acid-fast bacteria in urine. Can. Med. Assoc. J. 1970, 103, 283-284. [PubMed]

34. Yang, K.; Samplaski, M.; Mazzulli, T.; Lo, K.; Grober, E.; Jarvi, K.A. Urinary mycobacterium avium presenting as sterile pyuria. Can. Urol. Assoc. J. 2016, 10, E186-E188. [CrossRef] [PubMed] 
35. Pellman, C.M.; Runyon, E.H. The significance of mycobacteria other than tubercle bacillin in the urine: A report of forty-two cases. Am. Rev. Respir. Dis. 1964, 90, 243-247. [CrossRef] [PubMed]

36. Bodle, E.E.; Cunningham, J.A.; Della-Latta, P.; Schluger, N.W.; Saiman, L. Epidemiology of nontuberculous mycobacteria in patients without HIV infection, New York City. Emerg. Infect. Dis. 2008, 14, 390-396. [CrossRef] [PubMed]

37. Hawkins, C.C.; Gold, J.W.; Whimbey, E. Mycobacterium avium complex infections in patients with the acquired immunodeficiency syndrome. Ann. Intern. Med. 1986, 105, 184-188. [CrossRef] [PubMed]

38. Hampson, S.J.; Christmas, T.J.; Moss, M.T. Search for mycobacteria in interstitial cystitis using mycobacteria-specific DNA probes with signal amplification by polymerase chain reaction. Br. J. Urol. 1993, 72, 303-306. [CrossRef] [PubMed]

39. Tăbăran, A.F.; Matea, C.T.; Mocan, T. Silver Nanoparticles for the Therapy of Tuberculosis. Int. J. Nanomed. 2020, 15, 2231-2258. [CrossRef]

40. Griffith, D.E.; Eagle, G.; Thomson, R.; Aksamit, T.R.; Hasegawa, N.; Morimoto, K. Amikacin liposome inhalation suspension for treatment-refractory lung disease caused by Mycobacterium avium complex (CONVERT): A prospective, open-label, randomized study. Am. J. Respir. Crit. Care Med. 2018, 198, 1559-1569. [CrossRef]

41. Jaffré, J.; Aubry, A.; Maitre, T. Rational Choice of Antibiotics and Media for Mycobacterium avium Complex Drug Susceptibility Testing. Front. Microbiol. 2020, 11, 81. [CrossRef]

42. Clinical and Laboratory Standards Institute [CLSI]. Susceptibility Testing of Mycobacteria, Nocardiae, and Other Aerobic Actinomycetes, 2nd ed.; CLSI: Wayne, PA, USA, 2011.

43. Clinical and Laboratory Standards Institute [CLSI]. Susceptibility Testing of Mycobacteria, Nocardiae, and Other Aerobic Actinomycetes, 3rd ed.; CLSI: Wayne, PA, USA, 2018.

44. Haworth, C.S.; Banks, J.; Capstick, T.; Fisher, A.J.; Gorsuch, T.; Laurenson, I.F. British thoracic society guideline for the management of non-tuberculous Mycobacterial pulmonary disease (NTM-PD). BMJ Open Respir. Res. 2017, 4, e000242. [CrossRef]

45. Ferrero, J.L.; Bopp, B.A.; Marsh, K.C. Metabolism and disposition of clarithromycin in man. Drug Metab. Dispos. 1990, 18, 441-446. [PubMed]

46. Foulds, G.; Shepard, R.M.; Johnson, R.B. The pharmacokinetics of azithromycin in human serum and tissues. J. Antimicrob. Chemother. 1990, 25 (Suppl. A), 73-82. [CrossRef]

47. Acocella, G. Clinical pharmacokinetics of rifampicin. Clin. Pharm. 1978, 3, 108-127. [CrossRef] [PubMed]

48. Lee, C.S.; Brater, D.C.; Gambertoglio, J.G.; Benet, L.Z. Disposition kinetics of ethambutol in man. J. Pharm. Biopharm. 1980, 8, 335-346. [CrossRef]

49. Prescribers' Digital Reference. Streptomycin-Drug Summary. Available online: https://www.pdr.net/drug-summary/ streptomycin?druglabelid=1600 (accessed on 2 March 2021).

50. Hospira. Amikacin 250 mg/mL Injection. Updated 16 Sept 2015. Available online: https://www.medicines.org.uk/emc/ product/3784/smpc\#gref (accessed on 2 March 2021).

51. Wagenlehner, F.M.; Wydra, S.; Onda, H.; Kinzig-Schippers, M.; Sörgel, F.; Naber, K.G. Concentrations in plasma, urinary excretion, and bactericidal activity of linezolid (600 milligrams) versus those of ciprofloxacin (500 milligrams) in healthy volunteers receiving a single oral dose. Antimicrob. Agents Chemother. 2003, 47, 3789-3794. [CrossRef] [PubMed]

52. Stass, H.; Dalhoff, A.; Kubitza, D. Pharmacokinetics, safety, and tolerability of ascending single doses of moxifloxacin, a new 8-methoxy quinolone administered to healthy subjects. Antimicrob. Agents Chemother. 1998, 42, 2060-2065. [CrossRef] [PubMed]

53. van Heeswijk, R.P.; Dannemann, B.; Hoetelmans, R.M. Bedaquiline: A review of human pharmacokinetics and drug-drug interactions. J. Antimicrob. Chemother. 2014, 69, 2310-2318. [CrossRef]

54. Holdiness, M.R. Clinical pharmacokinetics of clofazimine. A review. Clin. Pharm. 1989, 16, 74-85. [CrossRef] 